\title{
The Implementation of Profit Sharing at Lembaga Perkreditan Desa
}

\author{
Ni Made Sri Ayuni ${ }^{1}$, Ni Wayan Novi Budiasni ${ }^{2}$
}

${ }^{1}$ Sekolah Tinggi Ilmu Ekonomi Satya Dharm

\section{A R T I C L E I N F O}

Article history:

Received 18 May 2020

Received in revised form

5 June 2020

Accepted 18 July 2020

Available online 29 August

2020

Keywords:

Financial performance,

transparency, profit sharing

\begin{abstract}
A B S T R A C T
Avoiding distortion of LPD funds requires transparency of financial reports and revenue sharing. Given that there are still frequent irregularities in the use of funds by the organizers. The purpose of this study was to determine the implications of financial performance and transparency on profit sharing. This research used quantitative methods from a population of 142 selected 60 samples. The data were collected by distributing questionnaires and collecting data on the number of samples in this study as many as 60 LPDs selected based on the stratified random sampling method. This study was analyzed using SEM (Structural Equation Modeling) analysis techniques with the PLS (Partial Least Square) method. Based on the first hypothesis, it shows that the relationship between financial performance variables and profit sharing shows the parameter coefficient value of 0.137 with a $t$ value of 1.350 . This value is smaller than
\end{abstract} the $t$ table $(1,960)$. The results of testing the second hypothesis indicate that the relationship between the transparency variable and profit sharing shows the parameter coefficient value of 0.724 with a t value of 8.179. This value is greater than the $t$ table $(1,960)$. Based on the research results, it can be concluded that financial performance has a positive relationship with profit sharing, and transparency has a positive relationship with profit sharing.

Copyright (C) Universitas Pendidikan Ganesha. All rights reserved. 


\section{Introduction}

Lembaga Perkreditan Desa (LPD) is a microfinance institution that develops and is established in villages in regencies, cities (Wilantinni \& Wirakusuma, 2019; Lestari, 2017). LPD as a microfinance institution is an institution that provides financial services to small and micro entrepreneurs as well as low-income people who are not served by formal financial institutions. This is in line with the purpose of establishing the LPD. The purpose of establishing an LPD is to improve the economy of rural communities where the LPD has several advantages, namely priority loans for people who want to start a business and the economy is low (Wilantinni \& Wirakusuma, 2019; Setia Dewi \& Suartana, 2018). Low interest rates, loan time only 1-5 years, adjusted for the size of the loan, certain loans can be submitted without collateral, and are not subject to administrative fees. To maintain the existence of the LPD, the LPD must provide financial reporting services in a timely manner. Submitting reports on activities, developments and liquidity of LPD regularly every month and reports on health level every 3 months to the Supervisor, BPD, PLPDK, and apparatus (Prajuru) of traditional villages.

However, the reality on the ground is different from what was expected where many LPDs in Bali experienced a crisis period and some even went bankrupt. Many factors that influence this can occur, for example, there is a large loan that is not repaid, and the expenditure is too large compared to the income generated and the accounting process is not transparent (Andreana \& Wirajaya, 2018). This statement is supported by the fact that there are still 91 LPDs in Badung that have not been published. The audit results are purely for the internal benefit of the LPD. If this problem is ignored, there will be considerable losses to the existing LPDs, even if there is an act of distorting LPD funds.

To avoid distortion of LPD funds, transparency in financial reports and profit sharing is required. Disclosure of the calculation of the rate of return and allocation of profits is very important to prevent financial institutions from manipulating earnings (Syanthi et al., 2017; Ningsih, 2015). On the other hand, increased transparency of bank financial conditions will also reduce information asymmetry so that market players can provide fair judgments and promote market discipline (Umiyati, 2020; Rodoni \& Yaman, 2018;). Adequate disclosure is the minimum level that must be met so that the financial statements as a whole are not misleading for the purpose of directed decision making. Fair or ethical disclosure is a level that must be achieved so that all parties receive the same treatment or information services. Full disclosure requires complete presentation of all information related to decision making. Being an LPD administrator must be honest if there will be legal sanctions as regulated in the PERDA (2012) concerning Administrative Sanctions, Investigations and Criminal Provisions. Apart from transparency in financial statements, transparency is also required in the profit-sharing process.

Profit sharing consists of two words, namely profit sharing and profit sharing. Sharing means cutting, dividing, breaking from the whole. Meanwhile, profit is the result of an act, whether intentional or not, both beneficial and harmful (Wibowo et al., 2018). Profit sharing is a system that includes the procedures for sharing the results of the business between the fund provider and the fund manager (Rahmawaty \& Yudina, 2015). In the economic dictionary, profit sharing is defined as profit sharing. Transparency and low bank performance have a negative effect on the implementation of the profit sharing system at the bank (Anggayana \& Wirajaya, 2019; Sawitri \& Ramantha, 2018).

Financial performance is a description of the achievement of the success of a company which can be interpreted as the results that have been achieved for various activities that have been carried out (Setia Dewi \& Suartana, 2018; Hartono, 2015). It can be explained that financial performance is an analysis carried out to see the extent to which a company has carried out using financial implementation rules properly. One of the models used in measuring company performance, especially LPD is the CAMEL financial ratio model. This model is also used by conventional banks to measure performance. The CAMEL model is an official measuring tool that has been established by Bank Indonesia to calculate the health of Islamic banks in Indonesia CAMEL and is a factor that greatly determines the health predicate of a bank (Sari, 2019; Murdiati \& Purwanto, 2014; Ratnaputri, 2013). The health of a bank is the ability of a bank to carry out normal banking operations and is able to fulfill all of its obligations properly in ways that are in accordance with applicable banking regulations and the assessment of bank health includes 4 criteria, namely a credit score of 81 to 100 (healthy), credit scores of 66 to 81 (fairly healthy), credit scores of 51 to 66 (unhealthy), and credit scores of 0 to 51 (unhealthy) (Sari, 2019).

Based on the results of research conducted by (N. P. M. Ch. Dewi \& Dewi, 2020) which stated that the effectiveness of the accounting information system and the user's technical capabilities have a positive effect on individual performance. Other research was also carried out by (Sari, 2019) stated that the results obtained are CAR, NPL, BOPO, NIM, ROA, ROE and LDR, PT. Bank Tabungan Negara, Tbk was 
declared unhealthy due to a decrease in the term management, in addition, from the side of profitability (ROA and ROE) there was also a decrease which caused banks to form allowance for impairment losses due to an increase in the ratio of non-performing loans or bad credit. Then the research conducted by (Anggayana \& Wirajaya, 2019) which stated that the principles of good governance which consist of transparency, accountability, responsibility, independence and equality partially have a positive effect on financial performance, while organizational culture has no effect on financial performance.

The difference between this study and previous research is 1) research conducted by (N. P. M. Ch. Dewi \& Dewi, 2020), the research is the effectiveness of the accounting information system and the technical ability of the user on the individual performance of the Village Credit Institution, 2) research conducted by (Sari, 2019) This research analyzed the health of the bank using the CAMEL method, 3) research conducted by (Anggayana \& Wirajaya, 2019) This study analyzes the principles of good governance and organizational culture on the financial performance of the Denpasar City Village Credit Institution. The purpose of this study was to analyze the implications of financial performance and transparency on the profit sharing that occurred in the LPD Buleleng Regency. So that the problem to be examined is financial performance and transparency have an effect on profit sharing. Researchers are interested in doing research in LPD Buleleng Regency because the Buleleng Regency area is part of the Province of Bali. Buleleng Regency consists of nine sub-districts, namely: Tejakula, Kubutambahan, Sawan, Buleleng, Sukasada, Banjar, Seririt, Busungbiu, and Gerogak Districts. The research was only conducted on LPDs that were still active in Buleleng.

\section{Methods}

In the early stages the researchers collected research data. The research data were collected by means of documentation and questionnaires distributed to 142 LPDs in Buleleng Regency. Furthermore, checking the feasibility of the questionnaire and testing the validity and reliability. And the data is tabulated according to the research variables. The data analysis tool used was SEM PLS. Finally, the research results are formulated and conclusions are drawn.

The sampling method used is probability sampling technique with the aim of providing equal opportunities for each member of the population. The LPD that will be the target of the research sample uses an error rate of $10 \%$. To determine the number of samples that represent the population, calculations are performed using the Slovin formula.

$$
\begin{aligned}
\mathrm{n} & =\mathrm{N} /\left(1+\left(\mathrm{N} \mathrm{x} \mathrm{e}^{2}\right)\right) \\
& =142 /(1+(142 \times 0.01) \\
& =142 / 1+1.42 \\
& =142 / 2.42 \\
& =59.7 \text { (60 rounded) }
\end{aligned}
$$

Note:

$\mathrm{n}=$ Sample size

$\mathrm{N}=$ Population

$\mathrm{e}=$ Margin of error

Researchers in collecting this data using questionnaires and documentation techniques. Documentation is used to collect in the form of financial reports and credit data held by the LPD. Furthermore, the questionnaire is used to collect data in the form of answers from respondents. The questionnaire data collection technique uses a Likert scale with intervals of 1 to 5 . The questionnaires will be distributed to 142 LPDs in Buleleng Regency. After the questionnaire was collected, the researcher tested its validity and reliability. The reliability test used Cronbach's Alpha, while the validity test was carried out by testing the correlation between the item score and the total score or comparing the correlation value ( $r$ count) with $r$ table. The SEM (Structural Equation Modeling) analysis technique with the PLS (Partial Least Square) method was used to analyze the data in this study (Ghozali, 2015). The data analysis stage is the first stage was to evaluate the measurement model (outer model). Test the validity and reliability by performing Convergent Validity, Discriminant Validity Composite Reliability, Cronbach's Alpha and AVE. Formative indicators were tested with weight significance and multicollinearity. The second stage was to evaluate the structural model (inner model). Evaluation in this model will be seen from the coefficient of determination (R2), predictive relevance (Q2), and goodness of git index (GoF). And performed a hypothesis test which was seen from the t-statistic value and the probability value. To test the hypothesis using statistical values, for alpha $5 \%$ the t-statistic value used is 1.96 . 


\section{Results and Discussions}

In this research, there were three constructs consisting of two exogenous variables, namely exogenous: financial performance (indicators: capital, assets, management, earnings and liquidity) and transparency (indicators: document readiness and accessibility, clarity and completeness of information, openness of processes and frameworks of regulations that guarantee transparency). Endogenous: Profit Sharing (indicators: level of investment, amount of available funds, and comparison of profit sharing, determination of income and expense items and accounting policies)

\section{Assess the Outer Model or Measurement Model}

The construct was said to have high reliability if the Composite Reliability value is above 0.70 , the Cronbach's Alpha value is above 0.60, rho_A is above 0.70, and AVE is above 0.50 (Ghozali, 2015). Table 3.1 presents the values of Cronbach's Alpha, rho_A, Composite Reliability and Average Variance Extracted (Ave) for all variables.

Table 1. Cronbachs Alpha, rho_A, Composite Reliability dan Average Variance Extracted (Ave) Value

\begin{tabular}{lllll}
\hline & Cronbach's Alpha & rho_A & $\begin{array}{l}\text { Composite } \\
\text { Reliability }\end{array}$ & \begin{tabular}{l} 
Average $\begin{array}{c}\text { Variance } \\
\text { Extracted (AVE) }\end{array}$ \\
\hline Financial Performance
\end{tabular} \\
Profit Sharing & 0.869 & 0.893 & 0.906 & 0.661 \\
Transparency & 0.880 & 0.897 & 0.915 & 0.686 \\
\hline
\end{tabular}

Table 1 shows that all the constructs in this study produce a Composite Reliability value above 0.70 and a Cronbach's Alpha value above 0.60. The lowest score for Composite Reliability is in the Transparency construct with a value of 0.853 and Cronbach's Alpha in the Transparency construct with a value of 0.785 . It can be concluded that the constructs in this study are reliable. Furthermore, the AVE value is above 0.5 for all constructs contained in the research model. The lowest AVE value is 0.594 in the transparency construct, so it can be concluded that the construct in this study is valid. The rho_A value is above 0.70 for all constructs.

Measuring the magnitude of the correlation between constructs and latent variables can also be seen in Figure 1. The path diagram is as follows:

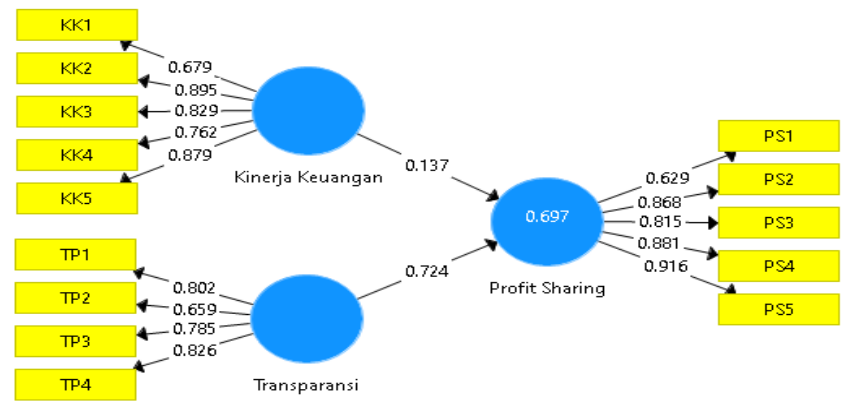

Source: Data processed

Picture 1. Score of Bootstrapping

\section{Structural Model Testing (Inner Model)}

In assessing the model with PLS, it starts by looking at the R-square for each dependent latent variable (Ghozali, 2015). Table 2 is the estimation result of R-square using SmartPLS

Table 2. r-Square Value

\begin{tabular}{lll}
\hline & R Square & R Square Adjusted \\
\hline Profit Sharing & 0.697 & 0.687 \\
\hline
\end{tabular}


Based on the coefficient of determination above, it is known that the R-Square value of Profit Sharing is 0.697 , the magnitude of the R-Square number is 0.697 which is equal to $6.97 \%$, and can be explained by the Financial Performance construct variable and Transparency.

\section{Hypothesis testing}

The basis used in testing the hypothesis is the value contained in the output result for inner weight. Table 3 provides the estimated output for testing the structural model

Table 3. Result for Inner Weight

\begin{tabular}{lllllll}
\hline & $\begin{array}{l}\text { Original } \\
\text { Sample } \\
(\mathbf{O})\end{array}$ & $\begin{array}{l}\text { Sample } \\
\text { Mean } \\
\text { (M) }\end{array}$ & $\begin{array}{l}\text { Standard } \\
\text { Deviation } \\
\text { (STDEV) }\end{array}$ & $\begin{array}{l}\text { T Statistics } \\
(\mid \mathbf{O} / \text { STDEV|) }\end{array}$ & $\begin{array}{l}\text { P } \\
\text { Values }\end{array}$ \\
\hline Financial Performance -> Profit Sharing & 0.137 & 0.146 & 0.101 & 1.350 & 0.178 \\
Transparency -> Profit Sharing & 0.724 & 0.725 & 0.088 & 8.179 & 0.000 \\
\hline
\end{tabular}

Based on Table 3, the results of testing the first hypothesis indicate that the relationship between financial performance variables and profit sharing shows the value of the parameter coefficient of 0.137 with a $t$ value of 1.350 . This value is smaller than the $t$ table $(1,960)$. The results of testing the second hypothesis indicate that the relationship between the transparency variable and profit sharing shows the parameter coefficient value of 0.724 with a t value of 8.179 . This value is greater than the table $(1,960)$.

\section{Discussion}

\section{Financial performance affects the Profit Sharing}

Financial performance is an analysis carried out to see the extent to which a company has implemented proper and correct financial implementation rules (Anggayana \& Wirajaya, 2019; As'ari, 2017; Rahmawaty \& Yudina, 2015). Meanwhile, profit sharing is a profit sharing system in which the owner of the capital works together with the executor of the capital to carry out business activities (Sudarsono \& Saputri, 2018; Santoso, 2016; Trishananto, 2016; Wardiah \& Ibrahim, 2013). Performance shows something related to the strengths and weaknesses of a company. These strengths are understood so that they can be used and weaknesses must be identified so that corrective steps can be taken. Bank performance can be measured by analyzing and evaluating financial statements. Performance is an important thing that must be achieved by every company anywhere, because performance is a reflection of the company's ability to manage and allocate its sources of funds. The results of testing the first hypothesis indicate that the relationship between financial performance variables and profit sharing shows the value of the parameter coefficient of 0.137 with a t value of 1.350 . This value is smaller than the $t$ table $(1,960)$. This is because the profit sharing obtained is determined based on the success of the fund manager to generate income. The ratio that describes the ability of a bank to manage the funds invested in all assets that generate income is ROA. If the ROA increases, the bank's income will also increase, with the increase in bank income, the profit-sharing rate received by customers will also increase. Thus it can be said that the higher the ROA, the higher the profit sharing received by the customer (Apriyantari \& Ramantha, 2018; Ismanto, 2018; Rahmawaty \& Yudina, 2015).

Previous research examined the existence of an indirect relationship between performance and profit allocation. In other words, the researcher argues that corporate governance mechanisms affect company performance which affects profit distribution. The results of testing the first hypothesis indicate that the relationship between financial performance variables and profit sharing shows the parameter coefficient value of 0.137 with a $t$ value of 1.350 . This value is smaller than $t$ table $(1,960)$. These results indicate that financial performance has no effect on profit sharing. This is because the Village Credit Institutions provide more benefits in accordance with the provisions already owned by the LPD. This is because many LPDs in Bali are experiencing a period of crisis and some even go bankrupt. The factors that influence this are the presence of a sizeable loan from the borrower and not returned, as well as expenses compared to the income generated and the bookkeeping process that is not transparent. This is supported by a statement (Riyadi \& Yulianto, 2014) the cause of the negative relationship between profit sharing financing on ROA is that the first customer who has received profit sharing financing from the bank does not necessarily return the funds obtained from the bank in the same year, then the second is because not necessarily all customers are obedient in returning the funds obtained from bank. In addition, there is research conducted by (Arfiani \& Mulazid, 2017) which stated that the Inflation variable has no influence on the Profit Sharing Rate variable. 
The results of this study are in line with research conducted by (Apriyantari \& Ramantha, 2018) which stated that earning assets have an effect on financial performance, capital adequacy has a positive effect on financial performance, and LDR has a positive effect on financial performance and this study also found that NPLs were able to moderate the effect of earning assets, and LDR on financial performance. Then the research conducted by (Ismanto, 2018) which stated that customer relationships and product quality produced by UKMs have a positive effect on customer satisfaction, while consumer satisfaction has a positive effect on the financial performance of UKMs in Jepara Regency and UKM's owners believe that having good customer relationships causes consumers to be satisfied with UKMs and will maintain loyalty to buy returns the resulting products so as to improve the financial performance of UKMs.

\section{Effect of Transparency on Profit Sharing}

Transparency is important to maintain people's trust in LPDs. Transparency, namely information is given without being covered. The LPD is a financial institution that deals with the community (krama Desa Pakraman), so it requires disclosure of financial information that can be accessed by the public in the form of community supervision of the LPD being considered. The application of the principle of transparency to the LPD can provide transparency of information about the condition of the LPD, while the application of the principle of accountability to the LPD can increase the trust of village manners to the LPD manager (Anggayana \& Wirajaya, 2019). The hypothesis shows that the relationship between transparency and profit-sharing variables shows the parameter coefficient value of 0.724 with a value of 8.179 . This value is greater than $t$ table $(1,960)$. This means that transparency has a positive and significant relationship to Revenue Sharing. This is because with transparency, all decision-making processes and provision of material information run well and always prioritize the principle of openness. Prioritizing the principle of openness or transparency is very well established to make customers have a sense of trust in financial institutions.

Transparency in a business is very important because with transparency, the public or krama will have confidence in a business activity or financial institution to entrust assets that are owned, whether in the form of goods or money (Nopiani et al., 2020; Iswahyudi et al., 2016). By developing an accurate accounting information system, it can increase transparency in financial management so that the information generated can help manage data more quickly, effectively and efficiently (K. C. Dewi et al., 2018). LPD must carry out transparency, it is hoped that it can increase the trust of the village community (Krama Desa Pakraman) in the LPD. This is because disclosing the calculation of the rate of return and allocation of profits is very important to prevent financial institutions from manipulating profits (Syanthi et al., 2017; Ningsih, 2015). On the other hand, increased transparency of bank financial conditions will also reduce information asymmetry so that market players can provide fair judgments and promote market discipline (Umiyati, 2020; Rodoni \& Yaman, 2018;).

The results of this research were in line with research conducted by (Anggayana \& Wirajaya, 2019) which stated that transparency has a positive effect on financial performance, accountability has a positive effect on financial performance, responsibility has a positive effect on financial performance, independence has a positive effect on financial performance, equality has a positive effect on financial performance, organizational culture has no effect on the financial performance of Village Credit Institutions in Denpasar City. Then the research conducted by (Sawitri \& Ramantha, 2018) which stated that transparency has a positive and significant impact on the performance of the Denpasar City Rural Bank.

\section{Conclusion}

Based on SEM (Structural Equation Modeling) analysis with the PLS (Partial Least Square) method, it is known that financial performance has no effect on the profit sharing of LPD in Buleleng Regency. LPD has its own Profit-Sharing method, where the profits generated will be used for the benefit of the village community (Krama Desa Pakraman). Second, transparency has a positive and significant relationship to the Profit Sharing at LPDs in Buleleng Regency. The Village Credit Institution must carry out transparency, it is hoped that it can increase the trust of the village community (Krama Desa Pakraman) in the LPD.

\section{References}

Andreana, M. O. C., \& Wirajaya, I. G. A. (2018). Pengaruh Transparancy, Accountability, Responsibility, Independency, dan Fairness Pada Kinerja Keuangan Lembaga Perkreditan Desa. E-Jurnal Akuntansi, 23, 1305. https://doi.org/10.24843/eja.2018.v23.i02.p19

Anggayana, I. P. N., \& Wirajaya, I. G. A. (2019). Pengaruh Prinsip-Prinsip Good Governance Dan Budaya 
Organisasi Terhadap Kinerja Keuangan Lembaga Perkreditan Desa Kota Denpasar. E-Jurnal Akuntansi, 29(1), 571-583. https://doi.org/https://doi.org/10.24843/EJA.2019.v29.i01.p21

Apriyantari, N. K. D., \& Ramantha, I. W. (2018). Pengaruh Aktiva Produktif , Kecukupan Modal , dan LDR Terhadap Kinerja Keuangan dengan NPL Sebagai Variabel Moderasi. E-Jurnal Akuntansi Universitas Udayana, 23(3), 2034-2060. https://doi.org/https://doi.org/10.24843/EJA.2018.v23.i03.p16 Pengaruh

Arfiani, L. R., \& Mulazid, A. S. (2017). Analisis Faktor-Faktor yang Mempengaruhi Tingkat Bagi Hasil Simpanan Mudharabah pada Bank Umum Syariah Indonesia Studi Kasus pada Bank Umum Syariah di Indonesia Periode 2011-2015. IQTISHADIA: Jurnal Ekonomi \& Perbankan Syariah, 4(1), 1. https://doi.org/10.19105/iqtishadia.v4i1.1132

As'ari, H. (2017). Analisis pengaruh struktur aktiva dan profitabilitas terhadap struktur modal dan kinerja perusahaan (studi kasus pada perusahaan BUMN yang terdaftar di BEI). Jurnal Riset Akuntansi Mercu Buana, 3(2), 68. https://doi.org/10.26486/jramb.v3i2.410

Dewi, K. C., Kurniawan, P. S., \& Yasa, I. N. P. (2018). Analisis efektifitas sistem informasi akuntansi dalam meningkatkan transparansi pengelolaan keuangan badan usaha milik desa (studi pada badan usaha milik Desa Mandala Giri Amertha Desa Tajun). 9(3), 26-37. https://doi.org/http://dx.doi.org/10.23887/jimat.v9i3.20418

Dewi, N. P. M. Ch., \& Dewi, A. A. (2020). Efektivitas Sistem Informasi Akuntansi dan Kemampuan Teknis Pengguna pada Kinerja Individual Lembaga Perkreditan Desa. E-Jurnal Akuntansi, 3(7), 1633-1644. https://doi.org/https://doi.org/10.24843/EJA.2020.v30.i07.p02

Ghozali, I. (2015). Structural Equation Modeling, Metode Alternatif dengan Partial Least Square (PLS). Edisi 4. Badan Penerbit UniversitasDiponogoro.

Hartono, A. (2015). Pengukuran Kinerja Keuangan dengan Metode Eagles (Studi Kasus Pada Bank BUMN yang Listing di BEI Tahun 2011-2013). Ekuilibrium, 10(2). https://doi.org/http://dx.doi.org/10.24269/ekuilibrium.v10i2.47

Ismanto, H. (2018). Kepuasan Konsumen dan Kinerja Keuangan UKM di Kabupaten Jepara. Jurnal Aplikasi Manajemen Dan Bisnis, 4(3). https://doi.org/http://dx.doi.org/10.17358/jabm.4.3.377

Iswahyudi, A., Triyuwono, I., \& Achsin, M. (2016). Hubungan Pemahaman Akuntabilitas, Transparansi, Partisipasi, Value For Money Dan Good Governance (Studi Empiris pada SKPD di Kabupaten Lumajang). Jurnal Ilmiah $\quad$ Akuntansi, $151-166$. https://doi.org/http://dx.doi.org/10.23887/jia.v1i2.9992

Lestari, I. G. A. O. S. I. (2017). Pengaruh Tingkat Efisiensi, Risiko Kredit, Dan Tingkat Penyaluran Kredit Pada Profitabilitas Lembaga Perkreditan Desa (LPD). E-Jurnal Akuntansi Universitas Udayana, 19(2), 1661-1690. https://ojs.unud.ac.id/index.php/Akuntansi/article/view/29778

Murdiati, S., \& Purwanto, M. T. (2014). Analisis Kinerja Dengan Pendekatan Rasio Camel. Jurnal Dinamika Manajemen, 5(1), 12-30. https://journal.unnes.ac.id/nju/index.php/jdm/article/view/3648/3405

Ningsih, S. (2015). Pengelolaan Laba Melalui Aktivitas-aktivitas Riil Perusahaan Perspektif Islam. Iqtishadia, 8(1), 93-110. https://doi.org/http://dx.doi.org/10.21043/iqtishadia.v8i1.1083

Nopiani, N. W., Atmadja, A. W. T., \& Musmini, L. S. (2020). Analisis Transparansi Sistem Pemberian Kredit Pada Usaha Simpan Pinjam Kesejahteraan Bersama Peringadi Banjar Adat Kawan Bangli. JIMAT (Jurnal Mahasiswa Ilmiah Akuntansi), https://doi.org/http://dx.doi.org/10.23887/jimat.v11i2.24978

Rahmawaty, R., \& Yudina, T. A. (2015). Pengaruh Return On Asset (ROA) dan Financing To Deposit Ratio (FDR) terhadap Tingkat Bagi Hasil Deposito Mudharabah pada Bank Umum Syariah. Jurnal Dinamika Akuntansi Dan Bisnis, 2(1), 92-103. https://doi.org/10.24815/jdab.v2i1.3623

Ratnaputri, W. (2013). The Analysis Of Islamic Bank Financial Performance By Using Camel, Shariah Conformity And Profitability (SCNP). Jurnal Dinamika Manajemen, 4(2), 215-226. https://doi.org/10.15294/jdm.v4i2.2765

Riyadi, S., \& Yulianto, A. (2014). Pengaruh Pembiayaan Bagi Hasil, Pembiayaan Jual Beli, Financing To Deposit Ratio (FDR) Dan Non Performing Financing (NPF) Terhadap Profitabilitas Bank Umum Syariah Di Indonesia. Accounting Analysis Journal, 3(4), 466-474. 
https://doi.org/10.15294/aaj.v3i4.4208

Rodoni, A., \& Yaman, B. (2018). Asymmetric Information and Non-Performing Financing: Study in The Indonesian Islamic Banking Industry. Al-Iqtishad: Jurnal Ilmu Ekonomi Syariah, 10(2), 403-416. https://doi.org/10.15408/aiq.v10i2.7392

Santoso, F. S. (2016). Analisis Perjanjian Modal Ventura Pola Bagi Hasil antara Kitab Undang-Undang Hukum Perdata dan Kompilasi Hukum Ekonomi Islam. Muqtasid: Jurnal Ekonomi Dan Perbankan Syariah, 7(2), 137. https://doi.org/10.18326/muqtasid.v7i2.137-148

Sari, R. K. (2019). Analisis Kesehatan Bank Dengan Metode Camel (Studi Kasus: Pt. Bank Tabungan Negara, Tbk Periode 2011-2015). Monex : Journal Research Accounting Politeknik Tegal, 8(1), 208. https://doi.org/10.30591/monex.v8i1.1115

Sawitri, P. P., \& Ramantha, I. W. (2018). Pengaruh Penerapan Prinsip-prinsip Good Corporate Governance Pada Kinerja Bank Perkreditan Rakyat di Kota Denpasar. E-Jurnal Akuntansi, 23, 1093. https://doi.org/10.24843/eja.2018.v23.i02.p11

Setia Dewi, I. G. A. A. M., \& Suartana, I. W. (2018). Analisis Komparatif Kinerja pada Lembaga Perkreditan Desa Kecamatan Mengwi dengan Metode Balanced Scorecard. E-Jurnal Akuntansi, 23(1), 651. https://doi.org/10.24843/eja.2018.v23.i01.p25

Sudarsono, H., \& Saputri, M. A. (2018). The Effect of Financial Performance toward Profit-Sharing Rate on Mudharabah Deposit of Sharia Banking in Indonesia. Muqtasid: Jurnal Ekonomi Dan Perbankan Syariah, 9(1), 82. https://doi.org/10.18326/muqtasid.v9i1.82-92

Syanthi, N. T. T., Sudarma, M., \& Saraswati, E. (2017). Dampak Manajemen Laba Terhadap Perencanaan Pajak Dan Persistensi Laba. EKUITAS (Jurnal Ekonomi Dan Keuangan), 17(2), 192. https://doi.org/10.24034/j25485024.y2013.v17.i2.2248

Trishananto, Y. (2016). Sistem Pengukuran Kinerja dan Kinerja Pembiayaan bagi Hasil Perbankan Syariah di Indonesia. Muqtasid: Jurnal Ekonomi Dan Perbankan Syariah, 7(2), 95. https://doi.org/10.18326/muqtasid.v7i2.95-116

Umiyati, L. M. M. K. (2020). Islamic Corporate Governance and Sharia Compliance on Financial Performance Sharia Bank in Indonesia. Al-IQTISHAD: Jurnal Ilmu Ekonomi Syariah (Journal of Islamic $\begin{array}{llll}\text { Economics), } 12 \text { 2020), 33-50. } & \text { no.1(Jan_juni }\end{array}$ https://doi.org/https://doi.org/10.15408/aiq.v12i1.15053

Wardiah, W., \& Ibrahim, A. (2013). Mekanisme Perhitungan Keuntungan Dan Pengaruhnya Terhadap Bagi Hasil (Studi Terhadap Pembiayaan Mudharabah Pada BPRS Hikmah Wakilah Banda Aceh). Share: Jurnal Ekonomi Dan Keuangan Islam, 2(1), 26-45. https://doi.org/10.22373/share.v2i1.1403

Wibowo, B. A., Amzul, R., \& Kuswanto, S. (2018). Efisiensi Penyaluran Kredit Ritel Komersial Terhadap Sektor UMKM di BRI (Studi Kasus di BRI Kantor Wilayah Jakarta 3). Jurnal Aplikasi Manajemen Dan Bisnis, 4(2), 308-316. https://doi.org/http://dx.doi.org/10.17358/jabm.4.2.308

Wilantinni, K. A. D., \& Wirakusuma, M. G. (2019). Pengaruh Pengendalian Internal Pada Efisiensi Kredit Di Lembaga Perkreditan Desa (LPD) Se-Kecamatan Sukawati Kabupaten Gianyar. E-Jurnal Akuntansi, 28(2), 874-902. https://doi.org/https://doi.org/10.24843/EJA.2019.v28.i02.p04 Pengaruh 